\title{
Michael: To the End of Pastoral
}

\author{
Dingming Wang \\ Department of English Sichuan Agricultural University, Ya’an, Sichuan, 625014, China \\ wangdingming@163.com
}

\begin{abstract}
As the title indicates, Michael is a poem of pastoral. With the passage of time, pastoral left its original theme. As the last poem in Lyrical Ballads (1800), Michael combines new kind of love theme and Christian elements together. The meaningful ending of Michael might indicate the end of this old genre.

Index Terms - Michael, pastoral, Wordsworth
\end{abstract}

\section{Introduction}

Michael: A Pastoral Poem, a serious blank verse poem, is the last work that Wordsworth added to the 1800 edition of Lyrical Ballads in order to replace Coleridge's unfinished poem, Christabel. Like the last poem, Tintern Abbey, which is the last poem of Lyrical Ballads and occupies the most important position in the first volume of the 1800 edition, Michael is regarded as the best one in the second volume. Early in 1920s, Knowlton argues Michael is "a novel pastoral" because it drops traditional love theme and amoebaean contest, and depicts "a real English shepherd." (446) Later, Page focuses on the basic issues of genre, style, and literary tradition. Though earlier Wordsworth was not a Christian, many critics read Michael from Biblical view. Harold Bloom talks it as "the most directly Biblical of Wordsworth's poems." (qtd. in Bushnell 246) Bushnell argues for an intriguing Wordsworthian irony in the poet's revision of the "Sacrifice of Isaac" narrative (250). Besides the reading of Michael from protagonists in Old Testament, Westbrook reads it as a parable, or a "metaparable," from the stories of New Testament (103). These arguments show the close connection of Michael to the traditional genre, Pastoral, and great influence of Christianity.

\section{Pastoral Tradition}

For the history of pastoral, it traces back to Theocritus, whose Idylls described how shepherds led an idealized existence of love and song. He was an educated man, and was interested in the foibles of country people. Conceiving the value of the charm of the folk songs, he refined them in order to please the courtly taste of his contemporaries. Then the pastoral idylls became popular. Later, Virgil made it as a vehicle for social comment. In Renaissance, Petrarch wrote in more realistic mood, and had it connected with contemporary society. When this tradition was adapted into English, Spenser and Pope kept it in simple style, and Gay made it more realistic. As a form of escape literature, when the pastoral was first established by Theocritus, it satisfied men's desire to escape from the pressures of urban life. In $17^{\text {th }}$ century, it gave men the realistic dream of retreating into countryside. At its first appearance, it was written in Alexandrine tone. Later it reached its peak of popularity in genres as drama, and the prose romance. In English it was written in elegy, and blank verse, like Milton's Lycidas, and Wordsworth's Michael.

\section{Pastoral Elements in Michael}

As Lessa has pointed out, Michael's subtitle challenged the notion of the pastoral in $19^{\text {th }}$ century England (191). Though the elements in the poem are quite different from the pastorals of the early stage, such as narrative, there are some pastoral elements in Michael.

\subsection{Story}

As Dorothy Wordsworth recorded, Michael was finished exactly on $9^{\text {th }}$ December 1800 (35). It is a combination of two local stories in Lake District. In one story, a couple lost their son. In another story, a shepherd worked 7 years on a shepherd fold. Michael, an abnormal strong man, representing "statesmen" in Northern England (Wordsworth Criticism 101), led a peaceful life "from the public way" (1. 1) ${ }^{1}$. With their industry, the house of Michael and his wife won the name of Evening Star among the community. When Luke, the only son of the family, was 18 years old, there came the distressful news that Michael should pay the forfeiture for a kinsman. Having thought for a long time, Michael decided to send Luke to earn money to pay the forfeiture. Before Luke's departure, Michael asked him to lay down the corner stone of the sheepfold. For Michael, the sheepfold was a covenant between the father and the son, and the shield of Luke. But Luke fell in the city, and never returned. With mysterious strength, Michael continued to live 7 years after the loss of his son. After his wife's death, the land was sold to a stranger, and only the oak and the unfinished sheepfold were left. Though Wordsworth combined two stories into one, but he didn't create them. Lack of originality gives similarity to traditional pastoral.

\subsection{Nature and Folk Life}

Though there is no dialect in the poem, with respect to conventional pastoral, Michael treats both nature and the life of simple folk. It is interesting that Michael was written shortly after the completing the Preface to Lyrical Ballads 1800 . This coincidence gives the possibility that this poem demonstrates the central doctrine of Preface, and Wordsworth's ideas about his art and his audience. First, the language is simple, and Michael's story is "Homely and rude" (1. 35), and chosen from "Low and rustic life" (Wordsworth Criticism 71). Second, it gives a scene close to Nature. In the very beginning of the poem, the narrator uses imperative voice to call the reader

\footnotetext{
${ }^{1}$ Unless otherwise stated, all quotations of Michael are from Cornell edition of Lyrical Ballads, and Other Poems, 1797-1800.
} 
"from the public way" to "the tumultuous brook of Green-head Gill" (11. 1-2). The reader discerns quite well that this story happens in a place remote from urban city. What happens there is subtle. Like the traditional pastoral, it makes one comfort in rural site, and escape from the anxieties developed in the city. The feeling developed there is the "utter solitude" (1. 13). But this solitude is the solitude without "habitation," because there are still "sheep," "rocks and stones, and kites" "sailing in the Sky" (11. 9, 11-2). The description makes a vivid scene which gives Nature the godhead and necessity of interpretation.

\subsection{Simplicity}

Departing from the traditional theme of love, Michael is realistic and simple. As the narrator relates, though selected from lower life, his story is fit "for the fire-side" (1. 20). Michael's long life was notable for his "stout of heart, and strong of limb" (1.42). He and his family were well known for their "endless industry" (1. 97). For, their house was named "The Evening Star" (1. 146). In Northern England of Wordsworth's time, it is easy to find statesmen with these characteristics. They worked on their small land the whole year and produced a great portion wealthy of society. Their stories were not as important as that of aristocrat, but were given significance. Here, "the feeling therein developed gives importance to the action and situation" (Wordsworth Criticism 73). What makes the significance of their stories is the feeling they have. In his letter to Charles James Fox, Wordsworth plainly said that those statesmen "who do not wear fine cloaths can feel deeply" (Wordsworth Criticism 102). Wordsworth believed these incidents, happened in the rural countryside, were capable to be used to trace "the primary laws of our nature", with "a certain colouring of imagination" (Wordsworth Criticism 71). The statements of Wordsworth prove that Michael indeed demonstrates what Wordsworth had just talked in his Preface.

\subsection{Theme of Love}

When Knowlton thought that Wordsworth had left the traditional theme of pastoral, the love affair and the contest of shepherds about love, he neglected there was another theme of love, the parental love and the love of property. When Wordsworth wrote Michael, the function of pastoral had changed a lot, enjoying a rural retreat. Michael is more realistic and treats the love of a man. Michael had different kind of love. To his land, it is the love of property, including the feelings of inheritance, home. He had "A pleasurable feeling of blind love" (1. 78). For his wife, "The Shepherd if he lov'd himself must needs / Have lov'd his Helpmate" (11. 1489). For his only son, Luke, it is parental love because he believed he was "bond" to him "by links of love" (11. 411-2). Those love echo in the whole poem, and demonstrate a forever theme of human being. The emphasis on love reveals the deep humanity. Man is a social animal. He has two kinds of relationship with the environment: nature and society. What Michael has are these two kinds of love. Comparing with the love affair of shepherd in traditional pastoral, Michael's topic is more wide and realistic, and touches more of humanity. It meets the requirement of contemporary needs of retreat, for Wordsworth himself had resided in Lake District in 1799. This poem, more or less, shows his idea of retreat from reality at that time. With those love, one conceives there is a real man, as Knowlton called "the ideal English shepherd" (439). Knowlton criticized some English poets, such as Milton and Pope, for their imitation of traditional pastoral, and praised Wordsworth's novelty of depicting the real English shepherd (439-40). From this point, Wordsworth actually had surpassed his predecessors and added new elements to pastoral.

\subsection{Biblical Elements}

Besides new love theme, Michael includes the biblical elements. When pastoral was introduced into English, there were many conventions of classical pastoral and machinery of paganism left behind in imitation. Though not the first one, Wordsworth used many biblical allusions. When Wordsworth was young, he was not a Christian. But in his later year, he converted to Established Church. Though not a Christian, young Wordsworth was familiar with Bible. He probably had read it throughout 1779-87 (Wu 15). He knew the characteristics of the Bible well. In his note to The Thorn, he talked about the virtues of repetition and tautology, which were shown "by innumerable passages from the Bible" (Wordsworth Criticism 97). Knowlton finds the language of Michael keeps the simplicity, which is "like that of the Bible, a respect wherein the poem resembles no previous pastoral in Greek, Latin, or English" (442).

Not only the language of Michael represents the Bible, but also there are many Biblical elements in this poem. For a long period, critics work hard and gain fruitful results in studying the biblical allegories in Michael. Roston, in Poet and Prophet: The Bible and the Growth of Romanticism, suggests the dependence on biblical names (Michael, Luke), figures (shepherd, patriarch), phrases (mess of pottage, helpmate), and images (unhewn stones) (qtd. in Westbrook 101). Bushnell studies the covenant built by Michael, and criticizes Michael's selfishness to sacrifice Luke preserve his land. These readings suggest the points of view from Old Testament, with reference to stories of Noah, Abraham, and Jacob, etc. But apparently, Luke's departure can deduce the story of Prodigal Son, which Westbrook treats as a parable recalling New Testament.

When Michael decided to send Luke to earn money in city, he made a choice between land and his son, a conflict between parental love and love of property. Michael resembles Abraham. He had Luke when he was 66 years old, as Abraham had Isaac at 99. Both sons were dear to them. Luke "was yet more dear" than his mother, "daily joy" of Michael, (11. 150, 345). But Michael is different from Abraham. For the faith of God, Abraham sacrificed his son, and the son was saved at the last moment by a ram offered by the angel. Abraham made a choice between the love of God and the love of son. Unfortunately Michael made a choice between the love of property and the love of son. Luke was not as fortunate as 
Isaac because his father was weak. Bushnell believes that Michael excluded Luke out of his love of Nature (249). It suggests that Michael was selfish. When Michael told his wife that he "could not lie quiet" in his grave because the fields should "pass into a Stranger's hand" (11. 240-1), it betrays his stern mind of possessing the land. Michael resembles Abraham, but he is not Abraham. The sacrifice of his son dooms the failure, because he sacrificed his son for the land instead of God. This irony shows the importance of belief in God.

When Michael led Luke to the place where he planed to build a sheepfold, he wished him to lay down the corner stone of the sheepfold. He told Luke that the sheepfold was "a covenant / 'Twill be between us" (11. 424-5). The covenant is a familiar image in Bible. God had established a covenant with Noah after the flood (Gen. 9:8). There was also a covenant between God and Abraham who sacrificed Isaac, his only son, without doubt (Gen. 23: 16). The laying down a stone also recalls the stone lay down by Jacob, who made covenant with Laban (Gen. 31: 44-5). But the covenant between the father and son has some questions. When Luke, as Jacob, laid down a stone, he did not build the covenant with his father, for Michael insisted the sheepfold, "A work which is not here", was the covenant (11. 424). As Bushnell argues that there has no covenant existing to begin with between father and son (252), Michael's covenant is just a future project in his mind because he regarded the finished sheepfold as the covenant instead a stone. He was weak that he could not build a covenant when he sent Luke off. Even this sheepfold could be anchor and shield of Luke against evil men, but before Luke had left before it was finished. Without the protection from the sheepfold, Luke failed to perform his duty, and resist the evil deeds, and run to foreign country. Luke was too early to be exposed to evil. With the unfinished sheepfold, there is no any covenant in this poem.

The unreturned son recalls a story in New Testament, The Prodigal Son. Westbrook refers Michael to three parables, The Lost Sheep, The Lost Coin, and The Prodigal Son, in the Bible (111). In The Prodigal Son, father rejoiced the return of his son (Luke 15: 32). In Michael, Luke never returned. The failure of Luke comes from some causes. Besides the weak character of Michael, Bushnell considers there is a failure of Luke's education, for preventing Luke forming his own ties to nature (248). From the poem, one learns Luke's education is unusual. When he was 5 years old, Michael gave Luke a staff and posted him "to stem or turn the Flock" (1. 195). Luke went to mountains with his father when he reached $10^{\text {th }}$ year of his life. His daily action was nothing else except endless industry. No evidence shows that he could communicate well with other people except his parents. Maybe he loved nature as his father.
But he had never learned how to deal with other people. His education is premature education at all. Otherwise, Michael was only a statesman with a small piece of land. Luke's departure was for money. It has nothing to do with one's virtue like the story of The Prodigal Son has demonstrated.

\section{Conclusion}

There are other reference to Bible, such as the mess of pottage, Shepherd's Staff, parish boy, Richard Bateman, name of the house, Evening Star, etc. The above ironic use of Biblical allusion shows that Wordsworth had introduced Christian elements into pastoral, as Knowlton calls it "a novel pastoral" (446). From the elements of pastoral and Christianity, Michael is truly a combination of tradition and Christian ideas. When Michael's land was sold, "the ploughshare has been through the ground" (11. 485-6). The land for sheep was changed into land for corns. Those lines suggest it is the end of Michael's possession of land, but they may have another meaning. From the theme and genre, even to the function of this poem, it is far from the original pastoral when Theocritus started with Idylls. But it still has the subtitle of pastoral, which symbolizes the genre of this poem. The end of Michael gives importance to the fate of pastoral. It might mean the end of pastoral. Wordsworth might not be conscious of this result when he wrote about the story. But the fact is that pastoral died out when Romanticism rose. Michael is the ploughshare that gives this end.

\section{References}

[1] Bushnell, John P., "Where is the Lamb for a Burnt Offering?": Michael's Covenant and Sacrifice," Wordsworth Circle, vol. 12, no. 3, pp. 246-52, Autumn 1981.

[2] Holy Bible: New Revised Standard Version, National TSPM \& CCC, 2000.

[3] Knowlton, E. C., "The Novelty of Wordsworth's Michael as a Pastoral," PMLA, vol. 35, no.4, pp. 432-446, 1920.

[4] Lessa, Richard, "Wordsworth's Michael and the Pastoral Tradition," University of Toronto Quarterly, vol. 53, no. 2, pp. 181-194, 1983.

[5] Manning, Peter J., Reading Romantics Texts and Contexts, NY: Oxford University Press, 1990.

[6] Page, Judith W., "A History/ Homely and Rude: Genre and Style in Wordsworth's Michael." Studies in English Literature, vol.29, no. 4, pp. 621-636, 1989.

[7] Westbrook, Deeanne, Wordsworth's Biblical Ghosts, NY: Palgrave, 2001.

[8] Wordsworth, Dorothy, The Grasmere Journals, Pamela Woof, ed., Oxford: Clarendon, 1991.

[9] Wordsworth, William, Wordsworth's Literary Criticism, W. J. B. Owen Eds., London: Routledge and Kegan Paul, 1974.

[10] Wordsworth, William, Lyrical Ballads, and Other Poems, 1797-1800. James Butler, and Karen Green Eds., Ithaca: Cornell University Press, 1992.

[11] Wu, Duncan, Wordsworth's Reading 1770-1799, Cambridge: Cambridge University Press, 1993. 